\title{
PKM Pengembangan Sumberdaya Manusia untuk Pemasaran Online Usaha Kecil Menengah "Kedurus Sejahtera" Surabaya
}

\author{
Anggraeny Puspaningtyas ${ }^{1}$, Abdul Halik ${ }^{2}$ \\ 1,2 Fakultas Ilmu Sosial dan Ilmu Politik, Universitas 17 Agustus 1945 Surabaya \\ Email : anggraenypupa@untag-sby.ac.id 1‥ halik@untag-sby.ac.id ${ }^{2}$
}

\begin{abstract}
The development of the creative economy during the 2015-2019 presidential administration encourages to increase Indonesia's economic growth. Systematically, it began with Presidential Instruction Number 6 of 2009 concerning Creative Economy Development by formulating the Master Plan for the Development of the Indonesian Creative Economy 2009-2025 by the Ministry of Trade of the Republic of Indonesia. In 2015 through Presidential Regulation Number 6 of 2015, the Creative Economy Agency to meet the complexity of the development of the creative economy, one of which is Small and Medium Enterprises engaged in handycraft crafts. Kedurus Sejahtera Embroidery or abbreviated as Kesra Embroidery is one of the fields of Small and Medium Enterprises in Surabaya that processes patchwork waste, combined with embroidery for the manufacture of bag and wallet products. Kesra Embroidery Small and Medium Enterprise has 21 members with limited product marketing and offline. The PKM program and partners agreed to solve the problem by 1) developing designs and marketing processes in online form, and 2) assisting in marketing bags and wallets online. From the development of the design and marketing process in the form of online can speed up and facilitate the marketing process. Online marketing management assistance can provide understanding and assistance in online marketing. The implementation method is partner identification, participatory learning and online marketing assistance
\end{abstract}

Keywords: Creative Economic Development, Online Marketing.

\begin{abstract}
Abstrak
Pengembangan ekonomi kreatif di periode pemerintahan presiden Tahun 2015-2019 mendorong untuk meningkatkan pertumbuhan ekonomi Indonesia. Secara sistematis dimulai dengan instruksi Presiden Nomor 6 Tahun 2009 tentang Pengembangan Ekonomi Kreatif dengan merumuskan Rencana Induk Pengembangan Ekonomi Kreatif Indonesia Tahun 2009-2025 oleh Kementerian Perdagangan Republik Indonesia. Pada tahun 2015 melalui Peraturan Presiden Nomor 6 Tahun 2015, Badan Ekonomi Kreatif untuk memenuhi kompleksitas perkembangan ekonomi kreatif, salah satunya adalah Usaha Kecil Menengah yang bergerak di bidang kerajinan handycraft. Kedurus Sejahtera Bordir atau disingkat Kesra Bordir adalah salah satu bidang Usaha Kecil Menengah di Surabaya yang mengolah limbah perca, digabung dengan bordir untuk pembuatan produk tas dan dompet. Usaha Kecil Menengah Kesra Bordir beranggotakan 21 orang dengan pemasaran produk terbatas dan secara offline. Program PKM bersama mitra sepakat untuk mengatasi permasalahan dengan cara 1) pengembangan desain dan proses pemasaran dalam bentuk online, dan 2) pendampingan pemasaran tas dan dompet secara online. Dari pengembangan desain dan proses pemasaran dalam bentuk online dapat mempercepat dan memudahkan proses pemasaran. Pendampingan pengelolaan pemasaran online dapat memberikan pemahaman dan pendampingan pemasaran online. Metode pelaksanaannya adalah identifikasi mitra, pembelajaran partisipatif dan pendampingan pemasaran online.
\end{abstract}

Kata kunci: Pengembangan Ekonomi Kreatif, Pemasaran Online. 


\section{PENDAHULUAN}

Latar Belakang: Kota Surabaya merupakan kota terbesar kedua di Indonesia dengan luas wilayah seluas $326,81 \mathrm{~km}^{2}$ dan jumlah penduduk sebanyak 1.367 .841 jiwa (sensus penduduk tahun 2010). Kota Surabaya sebagai pusat kegiatan di Provinsi Jawa Timur mendorong seluruh sektor bergerak untuk mewujudkan kesejahteraan masyarakat dan daya saing daerah. Sejak tahun 2013, Kota Surabaya telah memetakan kawasan berbasis potensi sumber daya alam. Sembilan kecamatan yaitu Kecamatan Sukolilo, Mulyorejo, Kenjeran, Bulak, Semampir, Asemrowo, Sambikerep, Mulyorejo dam Bubutan dibagi menjadi 3 wilayah pengembangan. Rata-rata seluruh kecamatan memiliki potensi produk hasil perikanan, produk olahan hasil perikanan dan pertanian dan produk daur ulang dan produk pariwisata.

Industri kerajinan tangan di Kota Surabaya, yang kini dipimpin Walikota Tri Rismaharini tumbuh 7\%-10\% dalam dua tahun terakhir. (Bisnis-jabar.com,Surabaya). Pertumbuhan industri kerajinan tangan di Surabaya itu tercapai seiring upaya pemerintah kota melakukan persiapan menghadapi Asean Free Trade Area (AFTA) 2015. Ketua Umum Dewan Kerajinan Nasional Daerah (Dekranasda) Kota Surabaya, mengatakan pertumbuhan industri kerajinan lokal itu salah satunya didorong oleh bertambahnya jumlah usaha kecil dan menengah (UKM). Untuk memperkenalkan produk kerajinan Surabaya, pemerintah mendukung dengan menggelar pameran di luar maupun dalam kota melalui program roadshow mall to mall. Faktor lainnya adalah transaksi penjualan barang kerajinan baik melalui pameran maupun di luar pameran.

Salah satu Usaha Kecil Menengah yang bergerak di bidang kerajinan handycraft di Surabaya adalah "Kedurus Sejahtera" atau "Kesra Bordir". UKM Kesra ini bergerak di bidang pembuatan tas dan dompet yang berbahan dasar kain jeans dengan aplikasi bordir kain perca. Pengertian Perca merupakan limbah potongan kain yang dipandang oleh sebagian orang merupakan sampah atau barang yang sudah tidak mempunyai manfaat lagi. Namun sebenarnya bagi sebagian orang yang kreatif, seperti ibu-ibu yang tergabung pada UKM Kesra, limbah perca ini bisa disulap menjadi berbagai macam produk baru yang sangat menarik. Hasil olahan perca bahkan mampu memberikan tambahan penghasilan keluarga. Keunikan dan kreativitas yang tertuang dalam kerajinan berbahan baku kain perca menjadi daya tarik tersendiri. Dengan harga jual barang yang relatif murah.

Produk yang dihasilkan UKM Kesra adalah paduan kain dengan perca menjadi berbagai macam kerajinan berupa dompet dengan beragam bentuk dan ukuran, tas untuk santai dan resmi yang memakai teknik bordir. Produksi kerajinan tersebut dikerjakan secara berkelanjutan. Adapun pemasaran produk UKM Kesra masih sangat terbatas yaitu dengan menerima pesanan dari dari konsumen, menitipkan barang produksi ke berbagai toko di mall, mengikuti bazar dan juga berbagai pameran khususnya di wilayah Gerbang kertasusila (Gresik, Bangkalan, Mojokerto, Surabaya, Sidoarjo dan Lamongan). Sedangkan pameran di luar Jawa Timur bila ada tawaran dari Dinas terkait.

Dalam berwirausaha perlu dilakukan kegiatan yang mengatur seluruh tahap kegiatan dari proses hingga menghasilkan suatu produk berupa jasa atau barang yang memberikan keuntungan pada pelaku wirausaha. Kegiatan ini bertujuan untuk meningkatkan efektifitas dan efisiensi dalam menjalankan usahanya. Salah satu bentuk manajemen yang paling penting adalah pemasaran. Selama ini UKM Kesra melakukan pemasaran dalam bentuk offline dan online, untuk pemasaran online masih kurang maksimal karena keterbatasan sumber daya manusia di bidang teknologi.

Di era digitalisasi, pemasaran online beragam jenisnya diantaranya website toko online, mobile marketing, dan video marketing. Website toko online adalah cara pemasaran dengan 
menggunakan website toko online atau menggunakan website domain berbayar atau gratis, dengan menggunakan website dapat menambahkan konten marketing yang dapat diakses oleh pembeli secara cepat dan tampil di awal pencarian. Mobile marketing merupakan cara pemasaran yang dilakukan secara online dengan menggunakan aplikasi messenger, dapat dilakukan secara pribadi maupun membuat suatu grup yang terdiri atas beberapa konsumen dengan memasarkan produk di dalam aplikasi tersebut. Video marketing adalah stratetgi pemasaran dengan media visual dengan menampilkan produk secara detail sehingga dapat dipercaya oleh konsumen, dengan video dapat meningkatkan kepercayaan dan pendapatan dari iklan yang berbayar atau banyaknya penonton (viewers) di video tersebut. Beberapa permasalahan yang dihadapi oleh Kelompok UKM Kedurus Sejahtera adalah sebagai berikut: Pemasaran yang hanya dilakukan dengan menitipkan kepada beberapa konter atau toko-toko, event bazar, pameran dan pemesanan dari konsumen saja, Manajemen pemasaran online yang belum dikelola secara baik, sehingga sulit untuk mengetahui perkembangannya. Kurangnya sumber daya manusia yang mumpuni dalam perkembangan teknologi.

Tujuan: adapun untuk mewujudkan pengembangan industri kreatif Indonesia dan meningkatkan kesejahteraan rakyat, tujuan pengembangan UKM Kesra adalah:

1. Meningkatnya daya kreasi rakyat di bidang industri kerajinan terutama kaum ibu dan remaja putri.

2. Menambah khasanah kerajinan /industri kreatif di Kota Surabaya.

3. Menumbuhkan wirausaha baru di bidang kerajinan di Kota Surabaya.

4. Meningkatkan keterampilan pada pembuatan model produk terbaru.

5. Inovasi kegiatan menciptakan desain dan produk bordir yang layak jual.

6. Praktek memasarkan produk dalam melalui pemanfaatan aplikasi menjadi media pemasaran online.

\section{METODE PELAKSANAAN}

Berdasarkan permasalahan yang dihadapi serta solusi yang ditawarkan maka pengusul kegiatan PKM menyampaikan beberapa metode pelaksanaan. Pertama, melakukan identifikasi beberapa permasalahan yang dihadapi oleh mitra UKM Kesra melalui survei awal, wawancara dengan mitra, dan observasi melihat beberapa anggota UKM Kesra waktu melakukan kegiatan, untuk mengetahui permasalahan yang paling mendesak. Kedua, berdasarkan hasil identifikasi beberapa permasalahan yang dihadapi pengerajin UKM Kesra Kedurus Kota Surabaya, selanjutnya di tentukan beberapa masalah yang krusial yang harus segera diatasi diantaranya membuat manajemen strategi produksi dan pemasaran berbasis online.

Metode pendekatan yang dilakukan adalah metode learning by doing. Dalam metode ini perajin dalam mengikuti pelatihan tidak harus dengan meninggalkan pekerjaannya. Akan tetapi dalam proses pelatihan bisa dilaksanakan bersamaan dengan saat perajin melakukan pekerjaannya. Dengan demikian diharapkan pelatihan yang diberikan dapat diterima dan dilaksanakan dengan baik. Selain itu, metode yang digunakan adalah metode partisipatif, yang diterapkan dalam proses pelatihan dan pendampingan ini dengan mengaktifkan keterlibatan para pengrajin dari limbah kain perca secara langsung dalam aplikasinya.

\section{HASIL dan PEMBAHASAN}

Kegiatan Program Kemitraan Masyarakat (PKM) yang diusulkan akan dilaksanakan oleh Tim yang terdiri dari 2 (dua) orang yang dan memiliki latar belakang ilmu yang berbeda dan banyak pengalaman pendampingan di bidang perancangan, pengembangan produk dan penerapan teknologi tepat guna bagi UKM dan masyarakat. Dapat diidentifikasikan beberapa 
permasalahan yang dihadapi oleh Kelompok Swadaya Masyarakat "Kedurus Sejahtera" adalah sebagai berikut:

1. Pemasaran yang hanya dilakukan dengan menitipkan kepada beberapa konter atau tokotoko, event bazar, pameran dan pemesanan dari konsumen saja.

2. Manajemen pemasaran online yang belum dikelola secara baik, sehingga sulit untuk mengetahui perkembangannya.

3. Kurangnya sumber daya manusia yang mumpuni dalam perkembangan teknologi.

Berdasarkan permasalahan yang dihadapi UKM Kesra ini, maka Pengusul Program PKM

bersama mitra sepakat untuk mengatasi permasalahan dengan berbagai cara diantaranya:

1. Untuk mengatasi kelemahan pengelolaan usaha, pengusul PKM mengadakan pelatihan dan pendampingan pengelolaan usaha, dan pembukuan/ keuangan.

2. Untuk meningkatkan pemasaran, pengusul PKM membantu proses pemasaran dengan cara:

a. Pelatihan teknik dan strategi pemasaran menggunakan media online.

b. Pendampingan pemasaran melalui media online seperti website, whatsapp, instagram dan sebagainya.

Sedangkan target Kegiatan PKM adalah :

1. Kelompok swadaya UKM Kesra dapat membuat manajemen usaha yang baik.

2. Operator pemasaran online yang terampil dalam pengoperasian software dan aplikasi.

3. Masyarakat yang peduli, mengetahui dan memahami pemanfaatan kain perca untuk barang yang lebih berguna lagi.

Di dalam belanja online, konsumen bisa mendapat banyak informasi harga, produk, dan kualitas tanpa bertemu langsung dengan penjual. Manfaat lain pemasaran online adalah jangkauan yang lebih luas; menghemat waktu, tenaga dan biaya; proses lebih mudah; serta mudah untuk dipantau. Hal-hal yang berkaitan dan mendukung pemasaran online adalah membutuhkan proses; hubungan dengan relasi dan customer lebih mudah; feedback atau imbal balik; dan simbosis mutualisme. Dalam menjalankan pemasaran online, UKM Kesra menggunakan media sosial facebook, whatsapp, instagram dan website. Pendampingan pemasaran dilakukan selama 7 kali untuk membuat konsep dan pengoperasian pemasaran online.

\section{KESIMPULAN}

Secara umum dengan pemasaran online yang meliputi kemudahan, informasi, evaluasi alternatif, keputusan pembelian dan perilaku pasca pembelian cukup menguntungkan bagi pihak konsumen dan produsen. Konsumen yang tidak punya banyak waktu dalam melakukan kegiatan belanja dan lebih efektif dan efisien sehingga memiliki pengaruh terhadap keputusan pembelian online. Kelompok swadaya UKM Kesra dapat membuat manajemen usaha yang baik dengan berbasis online.

\section{DAFTAR PUSTAKA}

Assauri, Sofjan. 2013. Manajemen Pemasaran. Jakarta: Rajawali Pers

Ayub, M. 2007. Understanding Islamic Finance (A-Z Keuangan Syariah). Jakarta: PT Gramedia Pustaka Utama

Basu, Swastha dan Irawan. 1998. Manajemen Pemasaran Modern. Yogyakarta: Liberty Handayaningrat, Soewarno. 1980. Pengantar Studi Administrasi dan Manajemen. Jakarta: PT Gunung Agung

Kotler, Philip. 2005. Manajemen Pemasaran Jilid I dan II. Jakarta: PT Indeks

Nawawi, Ismail. 2009. Public Policy, Analisis, Strategi Advokasi Teori dan Praktek. Surabaya: PMN. 